Available online at JIS website: https://jis.undip.ac.id

\author{
Research Article
}

\title{
Social Capital in Community-Based Waste Bank Management
}

\author{
Received: $29^{\text {th }}$ March 2019; Revised: $27^{\text {th }}$ November 2019; \\ Accepted: $9^{\text {th }}$ December 2019; Available online: $13^{\text {th }}$ December 2019
}

\section{Shafiera Amalia}

The Centre of Research and Education Training for Government Apparatus I, The National Institute of Public Administration , Jl. Kiara Payung Km.4.7 Jatinangor, Sukasari, Sumedang, 45366 Indonesia

\begin{abstract}
The waste bank is an innovative method to increase knowledge and behaviour to manage household waste. As a collective action at the community level, social capital has a vital role in the management of the waste bank. This study aims to identify and analyse how the level of trust, network, and social norms play a role in creating a sustainable, community-based waste bank management. This research used the qualitative approach and descriptive method. The data collection techniques were carried out using observations, literature studies, and in-depth interviews. The data were analysed using a qualitative-descriptive technique. The study shows that The Lintas Winongo Waste Bank is a community-based waste bank because it was established and managed by community members in RW 11, Bumijo Urban Village, Yogyakarta City. The manager of Lintas Winongo Waste Bank collaborates with several actors to support the management of the waste bank. The Lintas Winongo Waste bank management requires trust between the actors because it is related to the flow of money. The trust between the actors is built through the transparency of the waste bank management process. The network has a role in exchanging information and providing access to various resources required. The strategies to build networking with the actors are communication, shared understanding regarding the purpose of the waste bank, and a shared commitment to support the waste bank management. The social norms are required to maintain the transparency process and trust between the actors. Moreover, the social norm can build awareness of the citizens to manage domestic waste.
\end{abstract}

Keywords: Social Capital; Waste Bank Management; Community-Based; Sustainability

How to Cite: Shafiera, A. (2019). Social Capital in Community-Based Waste Bank Management. Jurnal Ilmu Sosial, 18 (2): 93-108 (doi: 10.14710/jis.18.2.2019.93-108), [Online]

Permalink/DOI: https://doi.org/10.14710/jis.18.2.2019.93-108

Corresponding Author: shafieraamalia@gmail.com (Shafiera Amalia) 


\section{Jurnal Ilmu Sosial Volume 18 | Issue 2 | December 2019 | Page 93-108}

\section{INTRODUCTION}

The waste bank is an innovative idea in waste management based on reduce, reuse, and recycle in Indonesia. The waste bank was first introduced by Bambang Suwerda in Badegan, Bantul, D.I Yogyakarta in 2008. Bambang Suwerda established the Gemah Ripah Waste Bank, which is distinct from the pattern of waste collection by collectors. In the Gemah Ripah Waste Bank, the pattern mimics the concepts used in the banking world. Waste that has been disaggregated is converted into money. The money comes from the results of waste processing. For example, organic waste will be processed into compost and sold; plastic waste can be crafted and sold; paper waste can be sold to collectors, and so on. Each member has a savings book. Waste deposited will be given a monetary value and neatly recorded. When it reaches a specific value, the money can be taken by the customer. However, collectors cannot accept all types of waste. They only receive a few types of inorganic waste which is then converted into money. Waste management conducted by the Gemah Ripah Waste Bank is highly comprehensive to ensure that all types of waste can be reused and have economic value.

Although waste management based on reduce, reuse, and recycle has been stipulated in the regulation, waste management in Indonesia is still dominantly use the old paradigm of collect - transport- disposal. The government is also still a major actor in waste management. According to the Directorate of Waste Management at the Ministry of Environment and Forestry, 66.39\% of waste management in Indonesia is still carried out by being stockpiled at the landfill. Community awareness and participation in managing (sorting and processing) waste are still low. The Central Statistics Agency (BPS) revealed that $76.31 \%$ of all households in Indonesia have not yet sorted household waste. Only $23.69 \%$ of households performed waste sorting, which consists of $10.28 \%$ of households performed sorting and utilizing, and as many as $13.41 \%$ performed waste sorting and discarded afterwards.

The waste bank aims to change people's behaviour in managing waste. The results showed that the mechanism of the waste bank could increase public awareness and participation in managing waste. Research conducted at the Malang Waste Bank Cooperative (BSM) shows that the implementation of BSM gradually changes the way of thinking and behaviour of citizens of Malang City in managing waste (Bachtiar et al., 2013: 132). Another study was conducted at Barokah Waste Bank, Lubuk Begalung Subdistrict, Padang. The results showed that the presence of a waste bank had changed the paradigm and mindset of the surrounding community regarding waste. The community has come to understand that waste is not an enemy but could hold a utility value and economic potential. The community is accustomed to being able to sort waste in the household for further depositing to the waste bank (Syafrini, 2013: 159-160). 


\section{Jurnal Ilmu Sosial Volume 18 | Issue 2 | December 2019 | Page 93-108}

Several benefits can be obtained from implementing a waste bank, namely changing the behaviour of the community in managing waste to reduce the amount of waste that goes into landfills. The waste bank can also develop the community economy from the sale of waste products. The waste products can be in the form of handicrafts, compost, ornamental plants, and organic plants (Sucipto, 2012). Thus, many regions have adopted and implemented waste banks in their areas. Areas that have implemented waste banks include Surabaya, Malang City, Bandung City, and Malang Regency. Statistically, the number of waste banks in Indonesia is increasing every year. In 2015-2016, there were 163,128 waste banks in Indonesia. The following table shows data on the number of waste banks in Indonesia from 2013 to 2016.

Table 1. The Number of Waste Banks in Indonesia 2013 - 2016

\begin{tabular}{lcc}
\hline No. & Year Period & Number of Waste Banks \\
\hline $\mathbf{1}$ & $2013-2014$ & 99,634 \\
$\mathbf{2}$ & $2014-2015$ & 151,419 \\
$\mathbf{3}$ & $2015-2016$ & 163,128 \\
\hline
\end{tabular}

Source: The Presentation of National Waste Management Information System, Directorate General of Garbage, Waste, and Hazardous and Toxic Materials Management of the Ministry of Environment and Forestry, 2017

In general, there are two local government strategies in implementing the waste bank program. The first is a top-down strategy. In this strategy, the regional government initiated the implementation of a waste bank by forming a central waste bank that is owned and managed by the government. After that, the local government encourage the community to form a waste bank unit in their area. The second is a bottom-up strategy. In this strategy, people who have the first initiative set up a waste bank. The government has a role in encouraging the community to establish a waste bank in their area. Thus, the waste bank is owned and managed by the community. Then, the local government build a central waste bank for waste management activities that unable to realize at the regional waste bank. 


\section{Jurnal Ilmu Sosial Volume 18 | Issue 2 | December 2019 | Page 93-108}

Waste bank management involves several actors, namely, the community, government and the private sector. In a community-based waste bank, the main actor is the community. As a collective movement at the community level, social capital has a vital role in managing a waste bank so that it can run effectively and sustainably. Some experts suggest that the accumulation of social capital in society contributes significantly to economic, social, and political performance (Nakagawa \& Shaw, 2004: 7). In the context of the environment, research shows that cognitive social capital encourages people to be pro-environmental (Liu et al., 2014: 190). More specifically, research also shows that social norms, as part of social capital, influence pro-environmental behaviour, including in waste management (Nordlund \& Garvill, 2002: 740).

The concept of social capital was first identified by Jacobs (1961), and Bourdieu (1986), Coleman $(1988,1990)$ compiled the conceptual framework, and Putnam $(1993$, 1995) further popularized it (Pretty \& Ward, 2001; Liu et al., 2014). The concept of social capital which includes social norms and social ties is an integral part of the basis of a sustainable life (Pretty \& Ward, 2001: 210). Several studies have shown that social capital at the community level can affect various outcomes in various fields, such as economics, innovation, health, and crime rates (Kwon et al., 2013: 982).

Putnam (1993) argues that social capital is a character of social organization, i.e. trust, norms, and networks that can improve community efficiency by facilitating coordinated action (Liu et al., 2014: 191). Social capital is a condition for collective action in various fields, including in the management of waste banks. Social capital facilitates/encourages coordination and cooperation between individuals or between actors involved in waste bank management. In the environmental program, the results of the study show that several components of social capital, namely trust, social norms, and networks have a positive effect on actions for environmental problems (Jones, 2010: 132).

Trust encourages and minimizes transaction costs in the process of collaboration and collective action (Pretty \& Ward, 2001: 211). The literature suggests there are two types of trust, namely individual trust and social trust. Putnam et al. (1993) suggested that social trust refers to the trust that is developed among individuals. Social trust is related to the tendency of individuals to take collective action (Jones, 2010: 124). In managing a waste bank, social trust influences the behaviour of individual community members to get involved in the program. Moreover, trust is an imaginative process to believe in the reliability of other actors in the collaborative process. This process is based on the reputation of the actor; evaluation of current conditions; assump- 


\section{Jurnal Ilmu Sosial Volume 18 | Issue 2 | December 2019 | Page 93-108}

tions about actor actions; and trust in the honesty and morality of other actors (Khodyakov, 2007).

Social networks are one element of social capital. Social networks are divided into two types, namely formal networks (participation in organizations) and informal networks (family networks, friendship) (Jones, 2010: 124). Social networks can also be classified into three categories, namely weak, strong, and multiplex ties: weak networks refer to formal business/work relationships; strong networks refer to informal business networks such as family support, close friends, community, and local communal relations; while multiple networks are built from a combination of strong and weak networks (Yetim, 2008: 869-870). In addition, the literature also groups social networks into three types, namely bonding, bridging, and linking. Bonding is an internal relationship in a community; for example, a family relationship or household environment. Bridging is a relationship between various social groups and the community. Meanwhile, linking is the relationship between various social groups from different strata and authorities (Jones, 2010: 124-125). In environmental programs, a social network is also a vehicle for exchanging information so that it can increase the participation of all actors (Jones, 2010: 125). More specifically, in the waste bank program, the network has a role in exchanging information and providing access to various resources needed to manage the waste bank.

The next element of social capital is social norms. Social norms are norms that are mutually agreed upon or which are inherited to behave, placing group interests rather than personal interests (Pretty \& Ward, 2001: 211). Putnam, et al. (1993), Narrayan \& Cassidy (2001) mention social norms can be formal and informal rules that encourage the common good and collective action (Jones, 2010: 124). Social norms and values can be considered as regulations that determine what is right and wrong in society. In an environmental context, the results of the study indicate that factors such as attitudes, values, beliefs, and social norms influence proenvironmental behaviour patterns (Díaz et al., 2012).

Research on social capital in the waste bank program is still limited. The previous study in 2011 studied the influence of social capital in the implementation of environmental policies that took the case in Mytilene, Greece. This research shows that social capital influences the compliance and cooperation of citizens in waste management and voluntary recycling programs. However, the findings show that there are differences in the effect of social capital components on citizens' behaviour in different environmental policy contexts (Jones et al., 2011: 264). In 2015, Yuanjaya conducted a study on social capital in the environmental movement which took the case in Kampung Gambiran and Gondolayu Lor Yogyakarta City. The results showed that social capital is particularly decisive in the environmental movement. Kampung Gambiran suc- 


\section{Jurnal Ilmu Sosial Volume 18 | Issue 2 | December 2019 | Page 93-108}

ceeded in changing the environmental conditions because the community had strong social capital, while Kampung Gondolayu Lor failed because the community had weak social capital (Yuanjaya, 2015: 70-71).

In 2017, Syahli and Sekarningrum researched social capital in managing Integrated Waste Management Sites in Bandung. The results showed that the management of Integrated Waste Management Sites runs effectively due to social capital (Syahli \& Sekarningrum, 2017: 150). However, these studies have not specifically examined the waste bank program. The waste bank program has a different mechanism compared to other environmental programs.

Thus, there are research gaps that illustrate the role of social capital in community-based waste bank management. Research conducted by Widodo in 2016 focused on the role of social capital in the management of the waste bank in the Brontokusuman Urban Village of Yogyakarta City. However, this research reveals more about the social values which bind trust, commitment, and mutually beneficial relations, so that the management of Waste Bank can run well (Widodo, 2014). Therefore, the novelty of this research explains how the role of social capital realized an effective and sustainable community-based waste bank management.

This research was conducted at the Lintas Winongo Waste Bank, Bumijo Urban Village, Yogyakarta City. This waste bank is established and managed by the community, not by the regional government. Since its establishment in 2009, Lintas Winongo Waste Bank has become the best and ever-growing waste bank in the Yogyakarta City. The actors involved in managing this waste bank include the community groups, the Environmental Service, and the private sector. This research will identify and analyze how the level of trust, networks, and social norms plays a role in creating/realizing sustainable community-based waste bank management.

\section{RESEARCH METHOD}

This research used a qualitative approach. The qualitative approach was chosen because this study seeks to understand and illustrate the role of social capital in the management of Lintas Winongo Waste Bank. The type of this research is descriptive research. Descriptive research seeks to describe a phenomenon or event that is happening presently. Descriptive research focuses on the actual problem as it is, without giving special treatment when the research was conducted (Noor, 2011).

The location of this research is in the Lintas Winongo Waste Bank RW 11, Bumijo Urban Village, Yogyakarta City. This waste bank was chosen because it is one of the community-based waste banks that continues to survive and develop in Yogyakarta City. The informants of this research are those who are directly involved in managing the Lintas Winongo Waste Bank. The 


\section{Jurnal Ilmu Sosial Volume 18 | Issue 2 | December 2019 | Page 93-108}

informant selection technique used is purposive sampling technique. Purposive sampling technique is a technique for selecting informants based on the consideration that the informants are those who understand the problem (Sugiyono, 2011). This technique is used to obtain informants who know about the operations of Lintas Winongo Waste Bank. Therefore, informants in this study comprise of: Yogyakarta City Legal Aid Institute; manager of Lintas Winongo Waste Bank; community members of Lintas Winongo Waste Bank customers; the waste collector UD Aneka Jaya (Trading Company); and the Paluma NGO.

In this study, there are two types of data collected, namely primary data and secondary data. As for some of the data collection techniques used in this study are literature study, observation, and in-depth interviews. In this study, the data obtained will be analyzed descriptively and qualitatively by understanding and compiling data that has been collected to describe it profoundly regarding the object studied, then arranged systematically, and lastly concluded. Thus, from this research, it will be comprehensively understood, and conclusions regarding the role of trust, networks, and social norms in realizing sustainable waste bank management can be drawn.

\section{RESULTS AND DISCUSSION}

Lintas Winongo Waste Bank was established in 2009. The establishment of Lintas Winongo Waste Bank was initiated by Mr Joko Sularno. At that time, he was Chairman of RW 11, Bumijo Urban Village, Yogyakarta City. The construction and development of the waste bank involved all residents of RW 11, especially the PKK (Family Welfare Movement) women in RW 11, to participate. Furthermore, the management structure of the waste bank was formed to operate the waste bank regularly. In addition to the management/manager, the routine operation of the Lintas Winongo Waste Bank is also assisted by each Dasawisma member in turn. Thus, Lintas Winongo Waste Bank was initiated, established and managed by community members in RW 11, Bumijo Urban Village, Yogyakarta City. In the operational process, the manager of the Lintas Winongo Waste Bank collaborates with many parties, including the Yogyakarta City Environment Agency, Paluma NGO, Panggung Lestari Village-Owned Enterprise; and UD Aneka Jaya (Trading Company) as collectors.

Lintas Winongo Waste Bank operates in RW 11 of Bumijo Urban Village which includes 5 RTs, namely RT 47, 48, 49, 50 and 51. Until 2015, the number of customers in Lintas Winongo Waste Bank was 235 households. Waste managed at Lintas Sampongo Waste Bank still focuses on the inorganic waste of various types. In addition to inorganic waste, Lintas Winongo Waste Bank also receives used cooking oil waste. In 2015, the amount of waste managed each 


\section{Jurnal Ilmu Sosial Volume 18 | Issue 2 | December 2019 | Page 93-108}

month was $831.12 \mathrm{~kg}$ of paper, $199.95 \mathrm{~kg}$ of glass, $329.83 \mathrm{~kg}$ of plastic, $70.95 \mathrm{~kg}$ of metal, and $16.25 \mathrm{~kg}$ of other waste. The turnover of Lintas Winongo Waste Bank every month is around Rp. $1,500,000$. In addition to managing inorganic waste savings, Lintas Winongo Waste Bank also provides a daily exchange of waste savings services (soap, shampoo, detergent, toothpaste, dishwashing liquid, floor cleaning liquid, tea, soy sauce, and butter). Furthermore, savings and loan services, reading parks, as well as waste management and recycling training are held not only for residents but also for members of institutions that come to Lintas Winongo Waste Bank.

Lintas Winongo Waste Bank operates routinely every Sunday between the hours of 08.00 - 12.00. When customers come with sorted waste, it is weighed and recorded in a ledger. The customer knows the results of the waste scale but does not yet know the money equivalent value. The manager collects, organizes, and records the total weight of the waste according to its type. The collectors take the waste and exchange it with money. After that, the manager deposits the money according to the customer's waste scales and moves the notes into the customer's saving book. After that, the customers can find out the value of their waste savings recorded in the savings book in the following week.

\section{Social Capital in the Management of Lintas Winongo Waste Bank}

Putnam et al. (1993) mention social trust related to the tendency of individuals to take collective action (Jones, 2010: 124). Moreover, Gachter et al. (2004) mention social trust related to the level of voluntary cooperation that can be developed between the various parties involved (Jones 2010: 124). Mayer (1995) argues that the perception of trust from one party (trustor) to another party (trustee) is diverse and can be categorized into forms of ability, benevolence, and integrity of the other party (trustee). Ability means that the competency of a party (trustee) to perform the expected action. Benevolence is a good and positive intention of another party (trustee). Integrity means that the other party (trustee) adheres to the principle accepted by the trustor. Integrity is related to honesty, fairness, consistency, and reliability (Fulmer \& Gelfand, 2013: 100).

Trust is needed in managing Lintas Winongo Waste Bank since many actors can be involved and participate in the program. Moreover, cooperation between actors built in the management of Lintas Winongo Waste Bank is a voluntary cooperation. In managing Lintas Winongo Waste Bank, the actors involved include the manager of the waste bank, collectors, and customers of the waste bank. Trust is also required because the activities of the waste bank are related to the flow of money. The customer entrusts the collected waste deposited to the waste bank saved as money. The waste bank converts the type of waste into money for the collectors. If 


\section{Jurnal Ilmu Sosial Volume 18 | Issue 2 | December 2019 | Page 93-108}

there are parties who act dishonestly - for example, collectors are in arrears and do not pay for the waste that has been taken - it can be detrimental and threaten the sustainability of the operations of the waste bank. The manager revealed that he had worked with dishonest collectors. Collectors are often in arrears in payment. This condition complicates the operation of the waste bank so it must stop the cooperation with the collectors. Therefore, these actors must have integrity and honesty so that they can be trusted by all parties, and the cooperation activities in managing a waste bank can be sustainable.

The process of building trust between the actors involved in managing the waste bank is carried out all the time while the participants work together. In managing the Lintas Winongo Waste Bank, trust between the actors is built and developed through a transparent and open process of waste bank management. Research conducted at non-profit organizations shows that information disclosure regarding performance, finance, and programs significantly influences trust in non-profit organizations (Farwell et al., 2018: 777). The results showed that a transparent process occurs in managers-collectors relations. According to Lintas Winongo Waste Bank Manager, collectors always make notes based on the type of waste that is more detailed than the waste bank, which is sometimes unknown to the manager. Collectors also never delay, and arrears waste payments.

Furthermore, a transparent process also occurs in the manager-customer relationship. The customer knows the price of each type of waste from collectors, and how much weight the waste is saved. In each type of waste weighing, the officers announce the amount of wight loudly so that the customer and the recording officer can hear it. Customers can also find out the record of their waste savings and cash flow of the waste bank. At the end of each year, customers can find out the year-end financial statements and the net income of all Lintas Winongo Waste Bank activities.

This trust is built and maintained, which causes the actors to remain committed to cooperating in managing the waste bank. The actors are actively involved in contributing to the management of the waste bank. The contribution is manifested in the role of each actor in the management of the waste bank. The manager has a role in carrying out routine waste and cooking oil savings services. The manager also carries out savings and loan activities and exchanges of waste with basic needs. Moreover, the manager actively carries out socialization and training related to waste management. Members of the customer community have a role in sorting the waste they produce. Then, the customer saves the garbage he has sorted to the waste bank regularly. The customer also participates in socialization and training organized by the manager. The collectors have a role in taking the garbage and converting each type of waste and its weight into 


\section{Jurnal Ilmu Sosial Volume 18 | Issue 2 | December 2019 | Page 93-108}

a regular rupiah value. For this reason, Lintas Winongo waste banks can continue to grow and develop in the city of Yogyakarta.

In environmental programs, social networks are a vehicle for exchanging information so that they can increase the participation of all actors (Jones, 2010: 124). In managing Lintas Winongo Waste Bank, the manager relates and cooperates with many parties to support the implementation of waste bank operations. These networks and relationships have a role in exchanging information and providing access to various resources needed to manage a waste bank. It is consistent with research findings on a microcredit program for poor women in India; a network formed because the program can increase access to basic needs that are needed. Moreover, the network increases social capital among participants (Davidson \& Sanyal, 2017: 1715).

The management of the Lintas Winongo Waste Bank has a relationship with several parties, namely the Yogyakarta City Environment Agency, Paluma NGO, Panggung Lestari VillageOwned Enterprise; and UD Aneka Jaya (Trading Company) as collectors. The Yogyakarta City Environment Agency provides training, consultation and infrastructure needed for managing a waste bank. Paluma NGOs also provide training and information related to household waste management to waste bank managers and customers. Meanwhile, Panggung Lestari VillageOwned Enterprise received a collection of used cooking oil waste which is also a service of Lintas Winongo Waste Bank and converted it into money. UD Aneka Jaya as a collector facilitates various types of disaggregated waste to be converted into rupiah value.

In managing Lintas Winongo Waste Bank, bonding, bridging, and linking social network have been created. The social bonding network is created from the relationship between the manager of the waste bank and the community members in RW 11, Bumijo Urban Village. Meanwhile, the bridging social network was formed from the relationship between the waste bank manager and the community organizations around RW 11 such as the hamlet (RW), neighbourhood (RT), dasawisma, and youth organization. The social linking network is created from the relations between waste bank managers and various organizations that have different entities, authorities, and strata such as the Yogyakarta City Environment Agency, Paluma NGO, Panggung Lestari Village-Owned Enterprises, and UD Aneka Jaya.

In order to build and maintain relationships between the actors in managing the Lintas Winongo Waste Bank, excellent communication is needed between the actors. In managing Lintas Winongo Waste Bank, the manager is the main actor who continues to establish communication and dialogue with other actors. The management actively communicates with all parties, both with collectors, Paluma NGOs and with the Environment Agency. This communication pattern is unique; the manager of Lintas Winongo Waste Bank has never held a special meeting be- 


\section{Jurnal Ilmu Sosial Volume 18 | Issue 2 | December 2019 | Page 93-108}

tween the parties. Based on the interviews with the management of the waste bank, communication between the manager and the parties is done mostly through WhatsApp media. The availability of cellular phones and computers connected to internet support the formation of social networks. The internet is a means to facilitate individuals, groups and organizations to carry out two -way communication (Haythornthwaite, 2005: 137). Besides, communication is also carried out through face to face. Therefore, the operation of the waste bank continues to run well.

In managing Lintas Winongo Waste Bank, every actor involved has the same understanding related to the objectives of the waste bank program. This shared understanding has led to a good relationship between the actors in the management of waste banks. The manager of Lintas Winongo Waste Bank as a key actor understands well what has been the goal of the waste bank since it was established. The goal of a waste bank is not profit-oriented. If the manager is profitoriented and the profit is not achieved, it can reduce enthusiasm and can cause the waste bank to be inactive and suspended animation.

From the results of the study, the manager of the waste bank has understood the ultimate goal of waste bank management. Managers are not profit-oriented but social and environmental goals. In the framework of ensuring the management's understanding of waste bank management, management members have not experienced change since it was formed in 2009. The manager recognizes the difficulty in finding community members who can replace management members who have good intentions and understanding of waste bank management. To overcome this, the manager of the waste bank has a thought to build the management and human resources (HR) of the waste bank so that it does not depend on just one or a few managers. Waste bank management must be carried out cooperatively by all members of the community. Therefore, the manager seeks to build human resources to have the will, knowledge, and skills to sort waste and run the operations of the waste bank. The manager provides understanding to community members to have social intentions and goals in managing the waste bank. Thus, the management and members of the community can understand the main objectives of waste bank management and the operation of the waste bank can be carried out alternately between all the management and members of the community.

Meanwhile, other actors already have an understanding of the objectives of waste bank management; including collectors. Collectors are private parties involved in the operation of the waste bank. As a private actor, it is very natural for collectors to be profit-oriented and not too concerned about the social and environmental goals of the waste bank. However, UD Aneka Jaya as collectors of the Lintas Winongo Waste Bank is different. This business owner understands what the ultimate goal of the waste bank. Long before the waste bank grew and developed in Yogyakarta City, the owner of UD Aneka Jaya already has a concern for the waste problem in 


\section{Jurnal Ilmu Sosial Volume 18 | Issue 2 | December 2019 | Page 93-108}

the city. With this shared understanding, collectors fully support the operations of the Lintas Winongo Waste Bank and do not pursue profits. The owner of UD Aneka Jaya revealed that collectors would take any amount of waste collected at Lintas Winongo Waste Bank. Nevertheless, it possible that the value of waste is insufficient to cover the operational costs (fuel, driver, and helper fee). Thus, when viewed in terms of income, it is unprofitable.

The Yogyakarta City Environment Agency also understands the goals of managing the Lintas Winongo Waste Bank. Managers and collectors have a shared vision to increase public awareness and behaviour in managing waste. The vision, mission and objectives of managers and collectors should in line with the objectives of the Agency. The Environment Agency is currently focusing on efforts to reduce waste and change people's behaviour in managing waste. The Paluma NGO also has a shared understanding regarding the objectives of managing the Lintas Winongo Waste Bank. One of the focus of Paluma NGO is empowering women and protecting the environment.

Besides the shared understanding of the waste bank objectives, the commitment between the actors also caused the relationship between the actors in the management of the waste bank to run well. The commitment that was formed in the cooperation relationship in the management of Lintas Winongo Waste Bank was due to the lengthy process in building the shared values and understanding between the actors. The manager of Lintas Winongo Waste Bank shows its commitment to routinely and consistently operate the waste bank, collecting and depositing used cooking oil, and continuously inviting the public to sort and manage waste. The manager also maintains its commitment by having a high willingness to learn related to waste management. If there is a training or workshop that is held by the Agency or other parties, the management is willing to follow it and implement it in a waste bank. The Environment Agency shows its commitment by continuously providing support for the management of Lintas Winongo Waste Bank, both in the form of training and in providing some of the infrastructure needed for the operation of the waste bank. Meanwhile, UD Aneka Jaya maintained its commitment by picking up disaggregated rubbish at the Lintas Winongo Waste Bank on a regular and timely basis. Paluma NGO maintains its commitment in managing the Lintas Winongo Waste Bank by providing market guarantees for used cooking oil collected at the Panggung Lestari Village-Owned Enterprise. Putnam, et.all (1993), Narrayan \& Cassidy (2001) state that social norms can be formal and informal rules that encourage collective good and collective action (Jones, 2010: 124). In an environmental context, the results of the study indicate that factors such as attitudes, values, beliefs and social norms influence pro-environmental behaviour patterns (Díaz et al., 2012). In managing Lintas Winongo Waste Bank, social norms that are formed among participants are informal 


\section{Jurnal Ilmu Sosial Volume 18 | Issue 2 | December 2019 | Page 93-108}

norms. Social norms are needed to maintain the value of transparency and trust between actors and build awareness of citizens to sort waste.

In managing Lintas Winongo Waste Bank, there are no formal written rules, but informal rules that originate from religious, cultural and customary teachings. The results showed that the actors held the value of cooperation, honesty and trust in cooperation in managing the waste bank. The collectors revealed that their involvement in the management of the waste bank was based on the religious values adopted. The collectors believe that their involvement in the management of the waste bank is part of worship in the context of maintaining environmental hygiene and health. The collectors also try to practice the value of honesty and trust in their role. Therefore, collectors always write down the number of waste scales correctly, without reducing or overdoing it. In addition, collectors also pay rubbish rupiah on time. The management also maintains the honesty and trust provided by the citizens in managing the waste bank. Actors' compliance with these informal rules can maintain trust among all actors involved in managing Lintas Winongo Waste Bank. If there are actors who are proven not to hold trust, then the actor will be excluded from cooperation. The high level of trust (trust) between actors causes formal regulations and regulations are not needed. This is consistent with the opinion of Fukuyama (1995) which states that when there are conditions that have a low level of trust, and there are few social norms, collaboration and collective action will work under a system of regulations and formal rules (Bullen \& Onyx, 2005).

Furthermore, the management of the Lintas Winongo Waste Bank also led to the formation of informal rules/new habits in waste management within the community of RW 11 , Bumijo Urban Village, Yogyakarta City. Managers do a lot of socialization and training on the management and sorting of household rubbish to the community around RW 11. Regular socialization and routine operation of the waste bank led to the creation of an informal rule (custom) related to how the management of household waste in the community of RW 11. This informal rule further increases community awareness and dynamic behaviour in managing and sorting household waste. In the context of environmental programs, Miller \& Buys (2008) suggested that created social norms will influence attitudes of care for the environment and can lead to environmental care behaviour (Jones, 2010: 124). Therefore, the community of RW 11 no longer processed household waste traditionally by collecting and disposal, but have adopted a pattern of 3R (Reduce, Reuse, and Recycle) waste management. The resulting household waste is sorted according to its type to be recycled. 


\section{Jurnal Ilmu Sosial Volume 18 | Issue 2 | December 2019 | Page 93-108}

\section{CONCLUSION}

The waste bank is an innovative method to increase public awareness and behaviour to manage household waste. The results of the study indicate that trust, networking, and social norms are aspects needed to realize sustainable management in the community-based waste bank. Trust is needed in managing the waste bank because there are many actors involved and participate in the program. Moreover, it is also required since the activities of the waste bank are related to the flow of money. In managing the waste bank, trust between the actors is built and developed through a transparent and open process.

Next, the manager of the waste bank is related and cooperates with many parties to support the implementation of the waste bank's operations. These networks and relationships have a role in exchanging information and providing access to various resources needed to manage the waste bank. To build and maintain relationships between actors in waste bank management, excellent communication between actors, shared understanding regarding the purpose of the waste bank, and commitment between actors to support the management of waste banks are required. In waste bank management, there are no formal written rules, but informal rules that originate from religious, cultural, and customary teachings. The compliance of the actors with these social norms can maintain the value of honesty and trust among each actor involved in managing the waste bank. Waste bank management causes the formation of informal rules/new habits in waste management in the community. This informal regulation increasingly increases the awareness and dynamic behaviour of the community in managing and sorting the household waste.

\section{ACKNOWLEDGEMENT}

Heartfelt thanks and appreciation to Prof. Dr. Agus Pramusinto, MDA who provided guidance and inspiration to the author. The author also conveys appreciation to those who are willing to provide the data and information needed while conducting research for this paper. These parties were the initiator and manager of the Lintas Winongo Waste Bank, Yogyakarta City Environment Agency, Paluma NGO, and UD. Aneka Jaya (Trading Company). The author states that there is no conflict of interest with other organizations related to the material contained in this paper. 


\section{Jurnal Ilmu Sosial Volume 18 | Issue 2 | December 2019 | Page 93-108}

\section{BIBLIOGRAPHY}

Bachtiar, H., Hanafi, I., \& Rozikin, M. (2013). Pengembangan Bank Sampah sebagai Bentuk Partisipasi Masyarakat dalam Pengelolaan Sampah (Studi Pada Koperasi Bank Sampah Malang). Jurnal Administrasi Publik, 3(1): 128-133 [Online]. Retrieved from http:// administrasipublik.studentjournal.ub.ac.id/index.php/jap/article/view/753 [Accessed April 10, 2019]

Bullen, P., \& Onyx, J. (2005). Measuring Social Capital in Five Communites in NSW: A Practitioner Guide. Coogee NSW

Davidson, T., \& Sanyal, P. (2017). Associational Participation and Network Expansion: Microcredit Self-Help Groups and Poor Women's Social Ties in Rural India. Social Forces, 95: 1695-1724 (doi: 10.1093/sf/sox021), [Online]

Díaz, M. J., Martínez, E., Piñeiro, C., Palavecinos, M., Benayas, J., \& Toribio, M. A. (2012). Involvement of Citizens in Hazardous Waste Management And Use of Recycling Centres in the City of Madrid (Spain). Waste Management and Research, 30(7): 689-699 (doi: 10.1177/0734242X11432189), [Online]

Farwell, M. M., Shier, M. L., \& Handy, F. (2018). Explaining Trust in Canadian Charities: The Influence of Public Perceptions of Accountability, Transparency, Familiarity and Institutional Trust. Voluntas, 30: 768-782, (doi: 10.1007/s11266-018-00046-8), [Online]

Fulmer, C. A., \& Gelfand, M. J. (2013). "How Do I Trust Thee? Dynamic Trust Patterns and Their Individual and Social Contextual Determinants". In K. Sycara, M. Gelfand, \& A. Abbe (Eds.), Models for Intercultural Collaboration and Negotiation. Spinger: p.100 (doi:10.1007/978-94-007-5574-1), [Online]

Haythornthwaite, C. (2005). Social Networks and Internet Connectivity Effects. Information, Communication \& Society, 8(2): 125-147 (doi:10.1080/13691180500146185), [Online]

Jones, N. (2010). Environmental Activation of Citizens in the Context of Policy Agenda Formation and the Influence of Social Capital. Social Science Journal, 47(1): 121-136 (doi:10.1016/j.soscij.2009.05.008), [Online]

Jones, N., Halvadakis, C. P., \& Sophoulis, C. M. (2011). Social Capital and Household Solid Waste Management Policies: a Case Study in Mytilene, Greece. Environmental Politics, 20 (2): 264-283 (doi:/10.1080/09644016.2011.551032), [Online]

Khodyakov, D. (2007). Trust as a Process: A three-Dimensional Approach. Sociology, 41(1): 115-132 (doi:10.1177/0038038507072285), [Online] 


\section{Jurnal Ilmu Sosial Volume 18 | Issue 2 | December 2019 | Page 93-108}

Kwon, S.-W., Heflin, C., \& Ruef, M. (2013). Community Social Capital and Entrepreneurship. American Sociological Review, 78(6): 980-1008 (doi:10.1177/0003122413506440), [Online]

Liu, J., Qu, H., Huang, D., Chen, G., Yue, X., Zhao, X., \& Liang, Z. (2014). The Role of Social Capital in Encouraging Residents' Pro-Environmental Behaviors in Community-Based Ecotourism. Tourism Management, 41: 190-201 (doi:10.1016/j.tourman.2013.08.016), [Online]

Nakagawa, Y., \& Shaw, R. (2004). Social Capital: A Missing Link to Disaster Recovery. International Journal of Mass Emergencies and Disasters, 22(1): 5-34. (doi:10.1017/ CBO9781107415324.004), [Online]

Noor, J. (2011). Metode Penelitian Skripsi, Tesis, Disertasi dan Karya Ilmiah. Jakarta: Kencana

Nordlund, A. M., \& Garvill, J. (2002). Value Structures Behind Proenvironmental Behavior. Environment and Behavior, 34(6): 740-756 (doi:10.1177/001391602237244), [Online]

Pretty, J., \& Ward, H. (2001). Migration, Social Capital and the Environment. World Development, 29(2): 209-227,(doi:10.1016/S0305-750X(00)00098-X), [Online]

Sucipto, C. D. (2012). Teknologi Pengolahan Daur Ulang Sampah. Yogyakarta: Gosyen Publishing

Sugiyono. (2011). Metode Penelitian Kuantitatif, Kualitatif dan R\&D. Bandung: Alfabeta

Syafrini, D. (2013). Bank Sampah: Mekanisme Pendorong Perubahan dalam Kehidupan Masyarakat (Studi Kasus: Bank Sampah Barokah Assalam Perumahan Dangau Teduh Kecamatan Lubuk Begalung Padang). Jurnal Humanis, 12(2): 155-167, (doi: 10.24036/ jh.v12i2.4035), [Online]

Syahli, R., \& Sekarningrum, B. (2017). Pengelolaan Sampah Berbasis Modal Sosial Masyarakat. SOSIOGLOBAL: Jurnal Pemikiran Dan Penelitian Sosiologi, 1(2): 143-151, (doi:10.24198/jsg.v1i2.13309), [Online]

Widodo, A. S. (2014). "Modal Sosial dalam Pengelolaan Bank Sampah". Thesis. Universitas Gadjah Mada

Yetim, N. (2008). Social Capital in Female Entrepreneurship. International Sociology, 23(6): 864-885 (doi:10.1177/0268580908095913), [Online]

Yuanjaya, P. (2015). Modal Sosial dalam Gerakan Lingkungan: Studi Kasus di Kampung Gambiran dan Gondolayu Lor, Kota Yogyakarta. Natapraja, 3(1): 57-72, (doi:10.21831/ jnp.v3i1.11958) [Online] 